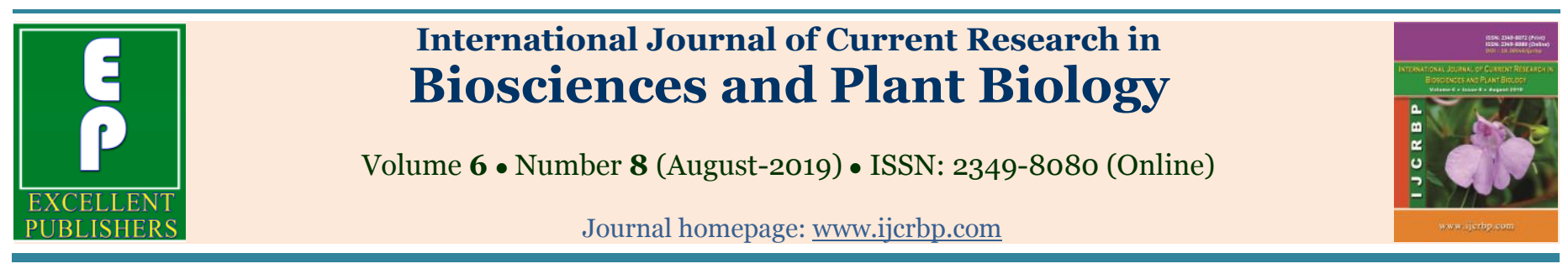

Original Research Article

doi: https://doi.org/10.20546/ijcrbp.2019.608.005

\title{
Weed hosts of major legume viruses in Niger State, Southern Guinea Savanna of Nigeria
}

\author{
Abdullahi A. Ahmed"1, M.G.M. Kolo², M.T. Salaudeen² and A. C. Wada ${ }^{2}$ \\ ${ }^{1}$ Department of Agricultural Technology, Niger State College of Agriculture, Mokwa, Nigeria \\ ${ }^{2}$ Department of Crop Production, Federal University of Technology, Minna, Nigeria \\ *Corresponding author; e-mail: drwada2013@gmail.com; Tel: +234-8067715561.
}

\begin{tabular}{|c|c|}
\hline Article Info & ABSTRACT \\
\hline $\begin{array}{l}\text { Date of Acceptance: } \\
26 \text { March } 2019\end{array}$ & \multirow{3}{*}{$\begin{array}{l}\text { Field surveys were conducted during the } 2015 \text { cropping season to identify and } \\
\text { determine the distribution of legume viruses in Niger State, Nigeria. A total of } 27 \\
\text { locations were visited during the surveys. Leaves were collected from weed plants } \\
\text { showing virus and virus-like symptoms in fields of cowpeas, groundnuts and soyabean. } \\
\text { Samples were also collected from asymptomatic plants within the vicinity of infected } \\
\text { plants. The antigen coated plate - enzyme linked immunosorbent assay (ACP -ELISA) } \\
\text { method was employed for virus detection in the collected leaf samples. Results showed } \\
\text { that Blackeye cowpea mosaic virus (BICMV), Cowpea mild mottle virus (CPMMV) and } \\
\text { Cowpea mottle virus (CPMoV) were the viruses detected. Thus Aeschynomene indica, } \\
\text { Amaranthus caudatum and Centrosema pubescens were positive to BICMV; while } \\
\text { Aspilia africana, Cleome viscera, Euphorbia hirta and Heterotis rotundifolia were } \\
\text { hosts of CPMoV and CPMMV was detected in Chenopodium amaranticolor, } \\
\text { Desmodium scorpiurus, and Vicia faba. The detection of these viruses in weed species } \\
\text { in the surveyed areas indicates their importance in the ecology, survival and the } \\
\text { significant role they play in the epiphytology of the various virus diseases. The } \\
\text { occurrence of BICMV, CPMoV and CPMMV in these weed species is believed to be the } \\
\text { first report in the study area. }\end{array}$} \\
\hline Keywords & \\
\hline $\begin{array}{l}\text { ACP-ELISA } \\
\text { Legume } \\
\text { Survey } \\
\text { Symptoms } \\
\text { Virus disease } \\
\text { Weed host }\end{array}$ & \\
\hline
\end{tabular}

\section{Introduction}

Cowpea (Vigna unguiculata [L.] Walp), groundnut (Arachis hypogaea L.) and soyabean (Glycine max [L.] Merril) are the major legumes in sub-Saharan Africa (Ndiaye, 1993; Batiano, 2011). The crops contribute bulk of the protein in the diets of millions of people (Vesper et al., 1999; Lokuruka, 2010). The grains of these crops are a major source of plant proteins for man, feed for animals, and a source of income (Diaz, 2005). Moreover, these plants play an important role in providing soil nitrogen to cereal crops such as maize, millet, and guinea when grown in rotation, especially in areas where poor soil fertility is a problem (Deacon, 1998; Herridge et al., 2008).

Virus diseases are considered a major limiting factor for the productivity of legumes in the tropical and sub-tropical countries (Bashir, 2008; Vincent et al., 2014; Palanga et al., 2016). One of the principal avenues by which these viruses are perpetuated is their over seasoning in weeds (Meliansyah et al., 2012; Makkouk et al., 
2015). For instance, it has been documented that perennial grasses in the lowland ecology or fadama, might be the original host of Rice yellow mottle virus from which it spreads to cultivated rice when conditions become favourable, especially after intensive cultivation (Salaudeen et al., 2008).

In addition, these weed species harbour plant viruses during the growing season and serve as sources of inocula for their secondary spread (Cooper and Jones, 2006; Meliansyah et al., 2012). Odedara et al. (2011) had reported that broad leaves and grasses which occur abundantly around legume fields could serve as alternative hosts and possibly be responsible for inoculum carry-over. Besides weeds competition with crop plants for space, nutrient and light and as host to insect pests, various weed species have been implicated in the epiphytology of viruses of some notable crops (Palanga et al., 2016). Salaudeen et al. (2008) reported that the Rice yellow mosaic virus which causes yield losses of between 25 and 100\% was harboured by weed species in the family Cyperaceae. Information on virus types and their weed hosts has a lot of implication on virus survival and epiphytology. The ultimate goal of such information is for designing sustainable management strategies against legume viruses. The objective of this study was, therefore, to identify the weed hosts of major legume viruses in Niger State, Southern Guinea Savanna of Nigeria.

\section{Materials and methods}

\section{Description of the study area}

Niger State is located in the Southern Guinea Savannah agro-ecological zone of Nigeria and lies between latitude $6^{\circ} 8^{\prime} \mathrm{E}$ and longitude $8^{\circ} 44^{\prime} \mathrm{N}$ of the equator. The site experiences distinct dry and wet seasons with an annual rainfall ranging from $1100 \mathrm{~mm}$ in the northern part to $1600 \mathrm{~mm}$ in the south with a mean of $1350 \mathrm{~mm}$. The rainfall which peaks in September normally begins in April and ends in October. The temperature ranges between 35 and $37.5^{\circ} \mathrm{C}$ with relative humidity between 40 and $80 \%$ in January.

\section{Collection of samples}

A field survey was conducted in major legume producing areas of Niger State with crops aged 6 9 weeks after planting in September and October, 2015. The state has 25 Local Government Areas (LGAs), grouped into three Agricultural zones. A multi-stage sampling procedure was employed to select three LGAs from each of the three zones, giving a total of 9 LGAs. Three villages/locations from the nine LGAs were randomly selected for the survey to give a total of 27 locations. Twenty leaf samples with symptoms such as leaf mottling, mosaic, leaf curling, distortion, chlorotic spots and stunting were collected from weed species growing from the edges and within the legume fields.

The weed species were botanically identified and classified by their morphological characteristics as described by Akobundu and Agyakwa (1987). The leaf samples were preserved over silica gels in airtight vial tubes. In each location, samples were collected at approximately 5 to $10 \mathrm{~km}$ from the previous sampled farm. Geographical location of each field denoting longitude and latitude was recorded using the Global Positioning System (GPS- 4300) equipment (Ethrex Garmin GPS, Taiwan) (Table 1).

\section{Serological detection of legume viruses}

The sampled leaves were subjected to antigen coated plate enzyme-linked immunosorbent assay (ACP - ELISA) as described by Kumar (2009) and absorbance values were quantified at $405 \mathrm{~nm}$ using a microplate reader (MRX, Dynex Technologies, Inc., USA) after overnight. Values were accepted to be positive when the optical density reading was at least twice that of the mean for the negative control.

\section{Results}

\section{Prevalence of characteristic virus symptoms}

The results showed that mosaic was the most prevalent symptom in all the locations surveyed. Leaf mottling was the next most rampant virus symptom observed during the survey. Leaf curl was another frequently encountered symptom followed by chlorosis, but not as rampant as the mosaic and leaf mottling symptoms. Stunting of plants, leaf puckering and deformation, dead of plants and others were also recorded but at specific locations only (Fig. 1). 
Table 1. GPS coordinates for locations where farms were surveyed.

\begin{tabular}{|c|c|c|}
\hline Town & Longitude/Latitude & Elevation \\
\hline Paiko Jazu & $\mathrm{O9}^{\circ} 25.672 \mathrm{~N} / \mathrm{Oo6}^{\circ} 39.447 \mathrm{E}$ & $353.0 \mathrm{~m}$ \\
\hline Tungan Makum & $09^{\circ} 29.291 \mathrm{~N} / \mathrm{Oo6}^{\circ} 37.384 \mathrm{E}$ & $277.4 \mathrm{~m}$ \\
\hline Kuta & $\mathrm{og}^{\circ} 51.479 \mathrm{~N} / \mathrm{oo6}^{\circ} 42.740 \mathrm{E}$ & $320.2 \mathrm{~m}$ \\
\hline Shiroro Dam & $\mathrm{og}^{\circ} 55.582 \mathrm{~N} / \mathrm{oog}^{\circ} 48.797 \mathrm{E}$ & $379.0 \mathrm{~m}$ \\
\hline Zungeru & $09^{\circ} 46.300 \mathrm{~N} / \mathrm{o06}^{\circ} 08.846 \mathrm{E}$ & $121.0 \mathrm{~m}$ \\
\hline Dabiri & $\mathrm{og}^{\circ} 35.895 \mathrm{~N} / \mathrm{oo6}^{\circ} 01.129 \mathrm{E}$ & $97.1 \mathrm{~m}$ \\
\hline Lemu & $09^{\circ} 22.290 \mathrm{~N} / 006^{\circ} 01.703 \mathrm{E}$ & $136.9 \mathrm{~m}$ \\
\hline Gidan Gwari & $09^{\circ} 14.440 \mathrm{~N} / 006^{\circ} 09.054 \mathrm{E}$ & $118.5 \mathrm{~m}$ \\
\hline Zachinta & $09^{\circ} 07.678 \mathrm{~N} / 005^{\circ} 54.765 \mathrm{E}$ & $153.3 \mathrm{~m}$ \\
\hline Kosteni & $\mathrm{og}^{\circ} 11.925 \mathrm{~N} / \mathrm{OO}^{\circ} 25.464 \mathrm{E}$ & $144.4 \mathrm{~m}$ \\
\hline Awuru & $\mathrm{og}^{\circ} 49.977 \mathrm{~N} / \mathrm{OO}^{\circ} 35.019 \mathrm{E}$ & $162.3 \mathrm{~m}$ \\
\hline Ba'aburasa & $\mathrm{og}^{\circ} 53.462 \mathrm{~N} / \mathrm{oO}^{\circ} 23.749 \mathrm{E}$ & $254.2 \mathrm{~m}$ \\
\hline Manigi & $\mathrm{og}^{\circ} 44.196 \mathrm{~N} / \mathrm{oO5}^{\circ} 28.901 \mathrm{E}$ & $215.4 \mathrm{~m}$ \\
\hline Makera & $\mathrm{og}^{\circ} 37.281 \mathrm{~N} /$ o050 $21.621 \mathrm{E}$ & $204.7 \mathrm{~m}$ \\
\hline Zugurma & $\mathrm{O}^{\circ} 28.909 \mathrm{~N} / \mathrm{oO}^{\circ}$ 57.315 E & $148.4 \mathrm{~m}$ \\
\hline Bokani & $\mathrm{Og}^{\circ} 26.958 \mathrm{~N} / \mathrm{OO}^{\circ} 93.490 \mathrm{E}$ & $163.1 \mathrm{~m}$ \\
\hline Mokwa & $\mathrm{O}^{\circ} 18.884 \mathrm{~N} / \mathrm{OO}^{\circ} 07.122 \mathrm{E}$ & $206.9 \mathrm{~m}$ \\
\hline Rafin Gora & $10^{\circ} 06.304 \mathrm{~N} / \mathrm{OO}^{\circ} 24.155 \mathrm{E}$ & $288.2 \mathrm{~m}$ \\
\hline Farin shenge & $10^{\circ} 24.453 \mathrm{~N} / \mathrm{oO}^{\circ} 30.859 \mathrm{E}$ & $346.3 \mathrm{~m}$ \\
\hline
\end{tabular}

Table 2. Reaction of weed species in Enzyme Linked Immunosorbent Assay (ELISA) in Niger State Southern Guinea Savanna of Nigeria in the year 2015.

\begin{tabular}{|c|c|c|c|c|c|c|c|c|}
\hline \multirow{2}{*}{ Weed species } & \multirow{2}{*}{$\begin{array}{l}\text { Growth } \\
\text { habit }\end{array}$} & \multicolumn{7}{|c|}{ Polyclonal antibody } \\
\hline & & CABMV & BICMV & CMV & SBMV & CPMoV & CYMV & CPMMV \\
\hline Ageratum conyzoides (Linn.) & $\mathrm{A}$ & 0.230 & 0.182 & 0.214 & 0.119 & 0.291 & 0.244 & 0.117 \\
\hline Aspilia africana (Pers.) C.D Adams & $\mathrm{A}$ & 0.221 & 0.231 & 0.091 & 0.201 & $0.382^{*}$ & 0.110 & 0.291 \\
\hline Cenchrus biflorus Roxb. & $\mathrm{A}$ & 0.229 & 0.197 & 0.239 & 0.103 & 0.154 & 0.249 & 0.102 \\
\hline Centrosema pubescens Benth. & $\mathrm{A}$ & 0.211 & $0.892^{*}$ & 0.101 & 0.199 & 0.127 & 0.102 & 0.110 \\
\hline Cleome viscosa $\mathrm{L}$. & $\mathrm{A}$ & 0.091 & 0.118 & 0.197 & 0.217 & $0.451^{*}$ & 0.228 & 0.102 \\
\hline Desmodium scorpiurus (Sw.) Desv. & $\mathrm{A}$ & 0.110 & $0.401^{*}$ & 0.120 & 0.193 & 0.207 & 0.229 & $0.494^{*}$ \\
\hline Euphorbia hirta (Linn.) & $\mathrm{A}$ & 0.211 & $0.291^{*}$ & 0.111 & 0.129 & $0.429 *$ & 0.221 & 0.098 \\
\hline Heterotis rotundifolia (SM) & $\mathrm{P}$ & 0.162 & 0.221 & 0.102 & 0.226 & $0.562^{*}$ & 0.081 & 0.170 \\
\hline Hyptis suaveolens (Poit) & $\mathrm{A}$ & 0.110 & 0.129 & $0.298^{*}$ & 0.190 & 0.281 & 0.153 & $0.461^{*}$ \\
\hline Laportea aestuans (L.) Chew. & $\mathrm{A}$ & 0.211 & 0.105 & 0.203 & 0.214 & 0.221 & 0.092 & 0.117 \\
\hline Diseased & & 2.138 & 2.377 & 2.586 & 2.140 & 2.584 & 0.262 & 0.452 \\
\hline Healthy & & 0.138 & 0.124 & 0.132 & 0.154 & 0.142 & 0.127 & 0.191 \\
\hline Buffer & & 0.128 & 0.141 & 0.138 & 0.167 & 0.141 & 0.165 & 0.214 \\
\hline
\end{tabular}

CABMV = Cowpea aphid borne mosaic virus; BICMV = Blackeye cowpea mosaic virus; CMV = Cucumber mosaic virus; SBMV = Southern bean mosaic virus; $\mathrm{CPMMV}=$ Cowpea mild mottle virus; $\mathrm{CMoV}=$ Cowpea mottle virus; $\mathrm{CPYMV}=$ Cowpea yellow mosaic virus. $\mathrm{A}=$ annual: $\mathrm{P}=$ perennial: * positive.

\section{Weed host of legume viruses}

Results obtained from the identification of weeds that are hosts to legume crops in Niger State, Southern Guinea Savanna of Nigeria using ACP ELISA are shown in Table 2. The results show the presence of viruses in some specific locations.
Blackeye cowpea mosaic virus (BICMV), cowpea mild mottle virus (CPMMV) and cowpea mottle virus $(\mathrm{CPMoV})$ were the only viruses detected in weeds. These viruses occurred in both single samples and mixtures of two or more collected leaves at the different locations surveyed. Specifically, BICMV was found in Dabiri, Farin 
Shinge, Gidan Kwano and Tatiko, CPMMV was detected in Farinn Shinge and Manigi while $\mathrm{CPMoV}$ was found in Awuru, Gidan Kwano, Lemu, Manigi, Mokwa and Tatiko. Similarly, Aeschynomene indica (Linn.), Amaranthus caudatum L., Centrosema pubescens Benth., Corchorus spp. (Jacq.) Willd. and Aspilia africana (Pers.) C.D Adams species, BICMV and Cleome viscosa L. were detected in the area hosting BICMV, CPMMV and CPMoV respectively.

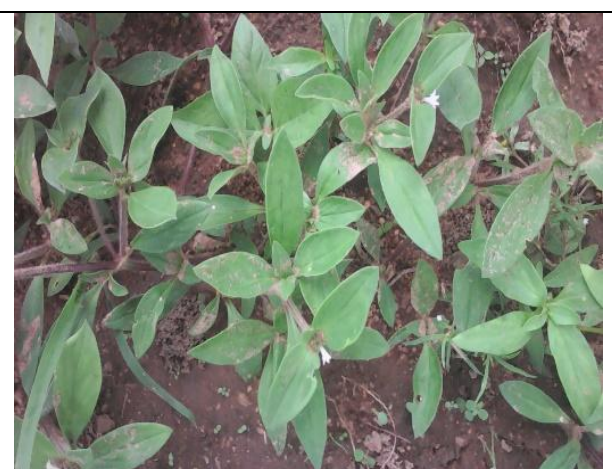

(A) Chenopodium amaranticolor (Coste \& Reyn)

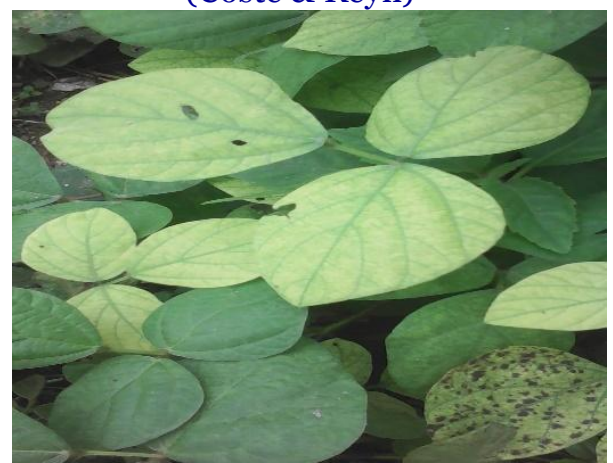

(D) Desmodium scorpiurus (Sw.) Desv.

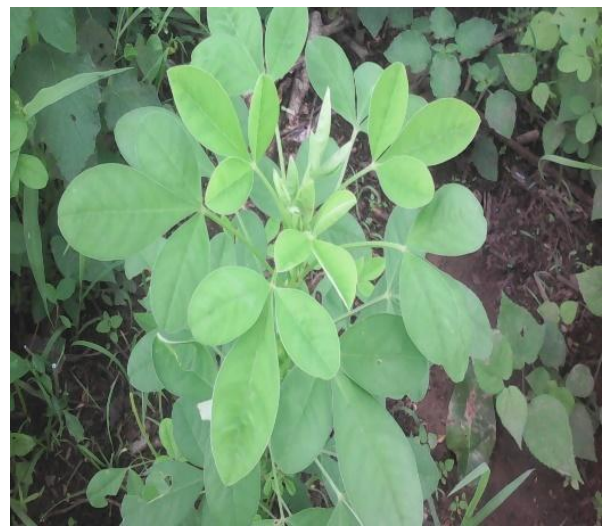

(G) Heterotis rotundifolia (SM)

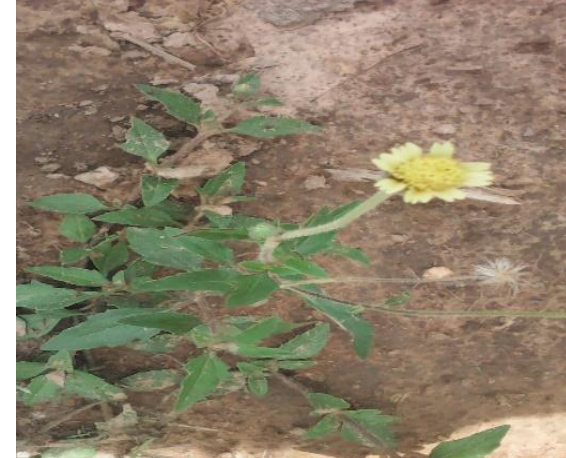

(B) Tridax procumbens Linn.

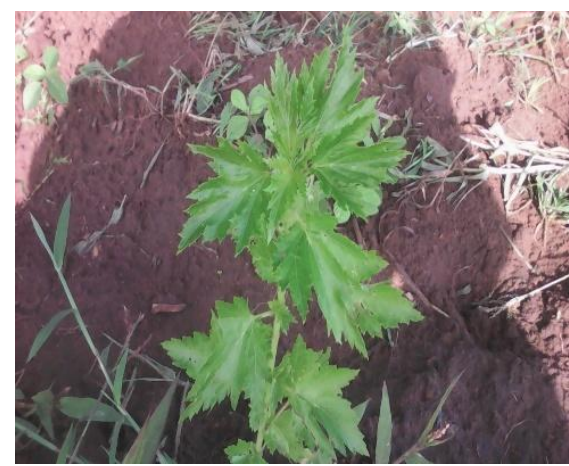

(E) Corchorus olitorius L.

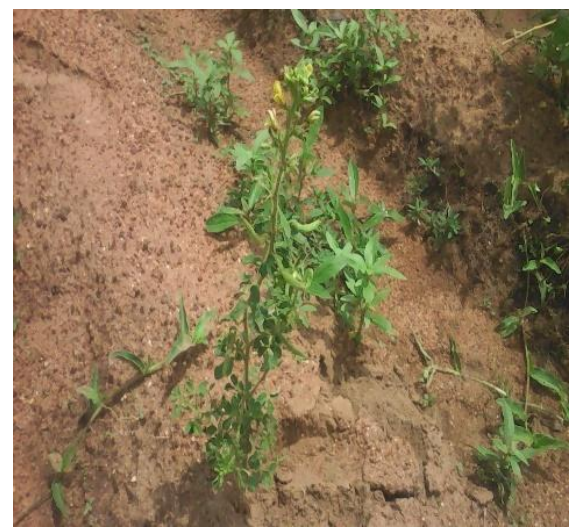

(H) Cleome viscosa $\mathrm{L}$.

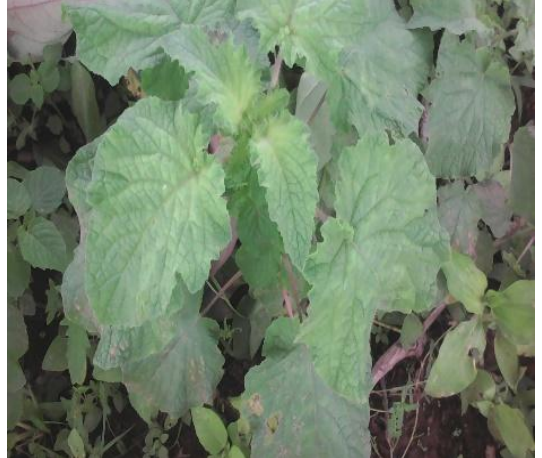

(C) Hyptis suaveolens (Poit)

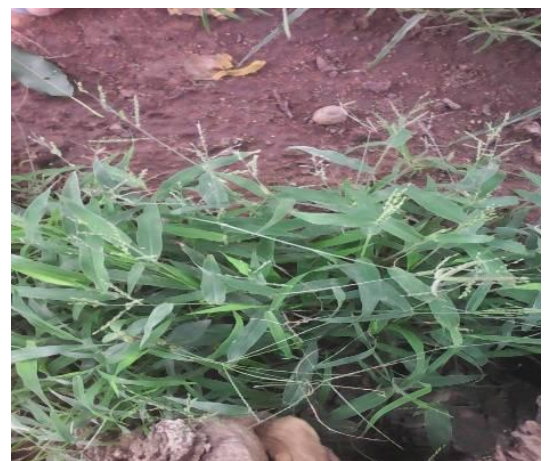

(F) Cenchrus biflorus Roxb.

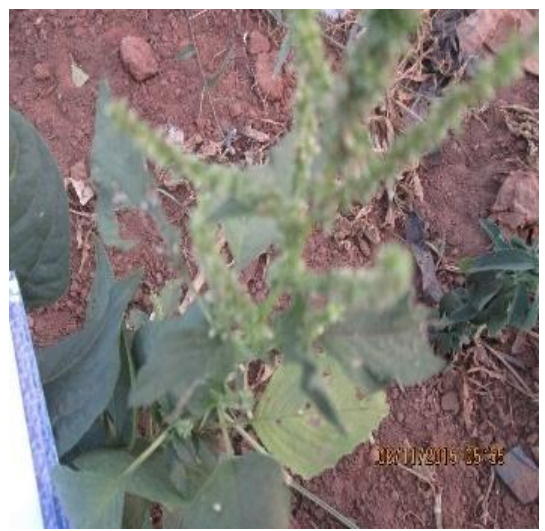

(I) Amaranthus caudatum L.

Fig. 1: Some weed samples with symptoms of virus infections during the 2015 survey.

\section{Discussion}

The virus symptoms which include leaf mottling, mosaic, leaf curling, distortion, chlorotic spots and stunting observed on the sampled weeds are in agreement with reports on viral infected legumes in the tropics by several workers (Shoyinka et al., 1997; El-Muadhidi et al., 2001; Najar et al., 2011; Makkouk et al., 2014). Occurrence, distribution and spread of these viruses could probably be influenced by environmental factors, presence of suitable and susceptible hosts and presence and 
activities of vectors. Incidence and distribution of the viruses were natural and may have stemmed primarily from seed infection and weed hosts as observed from the cropping pattern in the present study areas and as reported by Alabi et al. (2010).

The BICMV and CPMoV incidences recorded at Lemu and Dabiri which are separated by less than $5 \mathrm{~km}$ collaborate the findings of Aliyu et al. (2012) who discovered two different viruses from the same genus co-existing in the nearby field in Kwara State, Nigeria. This implies that subsequent mutation and replication of the viruses could simply result in several serotypes with varying degrees of virulence on the one hand and multiple infections of legume crops on the other. The occurrence of $\mathrm{CPMoV}$ and CPMMV in naturally infected cowpea witnessed from this study is believed to be the first report from Niger State. BICMV was detected at Awuru and Gidan-Kwano in mixture with CPMoV.

The $\mathrm{CPMoV}$ incidence was prevalent in Tatiko, Dabiri, Manigi, Awuru, Lemu and Mokwa locations. Although, Awuru is located at the riverine area which partially agrees with the report of Alegbejo (2015), who recorded high incidence of the pathogen in riverine areas of the middle belt of Nigeria which has a Southern savanna climate and where a lot of bambara groundnut is grown. Furthermore, this finding shows that the pathogen can also be spread to other areas within the Southern savanna which are not riverine. The seed borne nature of $\mathrm{CPMoV}$ and its recent detection among the surveyed legume crops, suggest that the virus could be spreading through seeds to other parts of the Southern guinea Agro-ecological zone of Nigeria.

Cowpea mild mottle virus has been reported to occur naturally in the middle belt of Nigeria which includes Niger State (Alegbejo, 2015). Odedara (2011) reported CPMoV as a seed-borne virus that is considered a major constraint to yield in legume fields. Due to emerging plants which quickly get exposed to virus inocula with greater damage at the early stages of crop plant development shows how important the virus can be in the study area.

The negative reaction of some of the weed leaf samples to ELISA in the present study implies that they belong to entirely different virus types or are non-legume viruses. The detection of $\mathrm{CPMoV}$ in some of the weed species indicates its importance in the ecology as well as its survival. Odedara (2011) reported that non-crop hosts of viruses can be particularly troublesome if they act as over seasoning hosts and remain unknown since bioassay must be carried out before to confirm their presence. The weed species which were implicated in the leaf samples from the surveyed legume fields show that they can harbour these pathogens during the growing season and serve as sources of inocula for their secondary spread. This is in agreement with report by Naimuddin, et al. (2014) who found Ageratum conyzoides harbouring Mungbean yellow mosaic India virus and thus acting as an important source of primary inoculum of the virus for the recurrence of yellow mosaic disease in grain legumes in northern India. Thus, these viruses can survive on these weed species during the off season and then serve as sources of primary inocula at the beginning of the new season.

Alegbejo (2015) earlier reported that the more important natural reservoirs of these pathogens are the annual weeds from theLeguminosae which can host the organisms all the year round and for extended numbers of years. Odedara (2011) also maintained that the viruses can also survive in infected dry leaves of the susceptible annual leguminous weed species, resulting in accumulation of virus inocula.

In the present study, Aeschynomene indica (Linn.), Amaranthus caudatum L., and Centrosema pubescens Benth. were among the common weed species in which viruses were detected in the study area. Hampton and Thottappilly (2003) reported that some of these forage legume species are naturally infected by these viruses. That $\mathrm{CPMMV}$ and $\mathrm{CPMoV}$ were detected in Corchorus spp. (Jacq.) Willd., and Aspilia africana (Pers.) C.D Adams, which is contrary to the work of Alegbejo (2015), who reported them as non-hosts. This might be due to differences in the virulence of the virus strains involved.

The detection of BICMV in Cleome viscera L., contradicts the findings of Odedara et al. (2011) who reported the weed as non-host of the virus and this can also be attributed to the virulence of the 
viruses strains assayed. Infection of Euphorbia hirta (Linn.) and Heterotis rotundifolia (SM) CPMMV in this study, is at variance with the report of (Alegbejo, 2015) who found them as only hosts of BICMV.

The infection of Hyptis suaveolens (Poit) by CPMMV, Aeschynomene indica L. and Centrosema pubescens Benth. by BICMV and Cleome viscera $\mathrm{L}$. by $\mathrm{CPMoV}$ viruses respectively under natural conditions as hosts in the field in the present study is a first report on them.

\section{Conclusion and recommendation}

Legume production in Niger State suffers from high virus infection with resultant substantial loss in grains. Virus diagnosis showed that three important legume viruses, BICMV, $\mathrm{CPMoV}$ and CPMMV were prevalent in some specific locations surveyed. Aeschynomene indica (Linn.), Amaranthus caudatum L., Centrosema pubescens Benth., Corchorus spp. (Jacq.) Willd., and Aspilia africana (Pers.) C.D Adams species and Cleome viscera $\mathrm{L}$ were detected in the area hosting BICMV, CPMMV and CPMoV respectively. There is, therefore, need for constant monitoring of legume crops fields through regular field disease surveillance and surveys to identify new and emerging weeds as starting point for legume viruses' management in the study area. Further studies should be carried out on the weed samples that showed weak positive and negative reactions to the identified viruses from this study in order to validate their roles in the virus-weed host-legume crops complex for their increased production to ensure food security.

\section{Conflict of interest statement}

Authors declare that they have no conflict of interest.

\section{References}

Akobundu, I.O., Agyakwa, C. W., 1987. A Handbook of West African Weeds. International Institute of Tropical Agriculture, Ibadan. Nigeria. 564p.

Alabi, O. J., Kumar, P. L., Mgechi-Ezeti, J. U., Naidu, R. A., 2010. Two new legume viruses (Genus Begomovirus) naturally infecting soybean in Nigeria. Arch. Virol. 155(5), 643656.

Alegbejo, M. D., 2015. Virus and virus-like diseases of crops in Nigeria. Zaria, Nigeria. Ahmadu Bello University Press. 273p.

Aliyu, T. H., Balogun, O. S., Kumar, L., 2012. Survey of the symptoms and viruses associated with cowpea (Vigna unguiculata (L.)) in the Agroecological zones of Kwara State, Nigeria. Ethiop. J. Environ. Stud. Manage. 5(4), 613-619.

Bashir, M., Ahamad, Z., Ghafoor, A., 2008. Cowpea aphid-borne mosaic potyvirus: A review. Int. J. Pest Manage. 48, 155-168.

Batiano, A., 2011. Fighting poverty in sub-Saharan Africa: The multiple roles of legumes in integrated soil fertility management. New York, Dordrecht 2011.

Cooper, I., Jones, R. A., 2006. Wild plants and viruses: under-investigated ecosystems. Adv. Virus Res. 67, 1-47.

El-Muadhidi, M. A., Makkouk, K., Kumari, S., Jerjess, M., 2001. Survey for legume and cereal viruses in Iraq. Phytopath. Mediterr. 40(3), 224-233.

Hampton, R. O., Thottappilly, G., 2003. Virus and virus-like diseases of major crops in developing countries (Eds.: Loebenstein, G., Thottappilly, G.), Kluwer Academic Publication. pp.355-376.

Herridge, D. F., Peoples, M. B., Boddey, R. M., 2008. Global inputs of biological nitrogen fixation in agricultural systems. Plant Soil. 311, 1-18.

IITA, 2012. International Institute of Tropical Agriculture Annual Report. Ouagadougou, Burkina Faso. IITA SAFURAD. pp.138-1932.

Kumar, L., 2009. Methods for the diagnosis of Plant Virus diseases. Laboratory Manual, Ibadan IITA. 94p.

Lokuruka, M. N. I., 2010. Soybean nutritional properties: The good and the bad about soy foods consumption- Review. Afr. J. Food Agric. Nutr. Dev. 10, 2439-2459.

Makkouk, K., Kumari, S. G., Leur van J. A. G., Jones, R. A. C., 2014. Control of plant virus diseases in cool-season legume crops. Adv. Virus Res. 90, 207-53.

Meliansyah, R., Hidayat, S., Mutaqin, K. H., 2012. Geminiviruses Associated with the Weed Species Ageratum conyzoides, Centipeda minima, Porophyllum ruderale and Silanthes iabadicensis from Java, Indonesia. Microbiol. 
Indonesia. 5(3), 120-124.

Naimuddin, M. A., Sanjeev, G., Aniruddha, K. A., 2014. Ageratum conyzoides harbours Mungbean yellow mosaic India virus. Plant Pathol. J. 13(1), 59-64.

Najar, A., Kumari, S. G., Attar, N., Lababidi, S., 2011. Present status of some virus diseases affecting legume crops in Tunisia, and partial characterization of Chickpea chlorotic stunt virus. Phytopathol. Mediterr. 50, 310-315.

Ndiaye, M., 1993. Cowpea viruses in Senegal, West Africa: Identification, distribution, seed transmission, and sources genetic resistance. Plant Dis. 77(10), 999-1003.

Odedara, O. O, Hughes, J., Odebode, A. C., Tarawali, S. A., 2011. Survey of viruses infecting herbaceous forage legumes in Nigeria. Acad. J. Plant Sci. 4(3), 69-76.

Palanga, E., Filloux, D., Martin, D.P., Fernandez, E., Gargani, D., Ferdinand, R., Zabré, J., Bouda, Z., Neya, J. B., Sawadogo, M., Traore, O., 2016. Metagenomic-based screening and molecular characterization of cowpea-infecting viruses in Burkina Faso. PLoS One 11(10), e0165188.
Prajapat, R., Marwal, A., Gaur, R., 2014. Begomovirus associated with alternative host weeds: A critical appraisal. Arch. Phytopathol. Plant Prot. 47(2), 157-170.

Riaz, M. N., 2005. Soy applications in food. CRC Press. 304p.

Salaudeen, M. T., Banwo, O. O., Kashina, B. D., Alegbejo, M. D., 2008. Identification of weed hosts of Rice yellow mottle Sobemovirus at Sayin Gobirawa, Northern Nigeria. Int. J. Agric. Rural Develop. 11(1), 108-112.

Shoyinka, S. A., Thottappilly, G., Adebayo, G. G., Anno-Nyako, F. O., 1997. Survey on cowpea virus incidence and distribution in Nigeria. Int. J. Pest Manage. 43(2), 127-132.

Vesper, H., Schmelz, E. M., Nikolova-Karakashian, M. N., Dillehay, D. L., Lynch, D. V., Merrill, A. H. Jr., 1999. Sphingolipids in food and the emerging importance of sphingolipids to nutrition. J. Nutr. 129, 1239-1250.

Vincent, S. J., Coutts, B. A., Jones, R. A., 2014. Effects of introduced and indigenous viruses on native plants: exploring their disease causing potential at the agro-ecological interface. PloS One 9(3), e91224.

\section{How to cite this article:}

Ahmed, A. A., Kolo, M.G.M., Salaudeen, M.T., Wada, A. C., 2019. Weed hosts of major legume viruses in Niger State, Southern Guinea Savanna of Nigeria. Int. J. Curr. Res. Biosci. Plant Biol. 6(8), 30-36.

doi: https://doi.org/10.20546/ijcrbp.2019.608.005 